\title{
Bertolt Brecht and Roger Howard: Revolutionary Theatre and Socio-Political Worries
}

\author{
Akram Shalghin \\ Jadara University, Jordan \\ E-mail: a.moulavi.n@gmail.com
}

Doi:10.7575/aiac.alls.v.5n.5p.94

Received: 27/06/2014

URL: http://dx.doi.org/10.7575/aiac.alls.v.5n.5p.94

Accepted: 25/08/2014

\begin{abstract}
This paper deals with the question of revolutionary literary texts. It examines the painful, or even brutal, measures that could be taken at times when the revolutionary figures depicted in the literary texts are themselves subject to control by a party line. While this paper shows that the noble intentions would not suffice for conducting revolutionary acts in Brecht, it also argues for the necessity of considering even tiny steps as positive historical contributions in Howard.
\end{abstract}

Keywords: Brecht, party line, plans vs reality, Howard, British history as a dream.

\section{Introduction}

It has been often discussed that literature can be properly understood within a broad way of accounting for its sociopolitical connectivity. It is, therefore, central when approaching a literary text to frame its relationship within its contemporary social and political context. (Note ${ }^{1}$ ) Certain literary texts seem not only as the embodiment of this view regarding the relationship to society but also they possess keys to social adjustments. Revolutionary playwrights, whose aim is social change, design their texts as more than just records or monitors of their own political spheres, but rather as active contributors or even creators of the realities of the political scenes. On this basis, the following pages will be dealing with the dramatic structure and the social and political ideas advocated by Bertolt Brecht in the Measures Taken and Roger Howard in Britannia. There will be an investigation of how Brecht and Howard approach the issues of knowledge and power that are used as ideological apparatuses.

\section{Brecht and Howard}

Brecht's theory on the theatre was drawn mostly from experience; his writings on theatre were mostly pragmatic, concerned with how to make a revolutionary art. His 'learning' plays are largely stylised texts on the problematics of bringing about a social advance. These 'learning' plays are meant to instruct both the actors and the audience. And, as Brecht assumes, these learning plays "would not be taken for granted by the spectator and would arouse him to think; it became obvious to him which were right actions and which were wrong ones."(Note ${ }^{2}$ )

Howard maintains that his responsibility in writing plays is to make a sort of 'record' about oppressive conditions in his society. Howard clarifies that "if it's our business to think, our thoughts need clearly to be turned towards contradicting this successful oppression." (Note ${ }^{3}$ ) He goes farther to illustrate that every single act, in one way or another, inputs to a process making in history and that contribution depends on the quality of the act in question. He points out that he seeks to make "a dialectical representation of reality, ripe with contradictions -which- not being static, and human beings being capable of consciousness - can be transformed by human beings."(Note ${ }^{4}$ )

Among Brecht's "learning" plays is The Measures Taken, it is presented in a flashback, and it employs a dramatic manner which brings to mind and to life his essay "Street Scene."(Note ${ }^{5}$ ) In The Measures Taken, Four Agitators return from China to Moscow and give an account or rather 'report' to the Control Chorus who actually represents "The Central Commission of the Party" (Comintern), about their successful propagation mission of Marxist thought among the Chinese workers. In this report, they refer to the death of a Young Comrade who has been appointed as an assistant to them. The Four Agitators demonstrate to the Control Chorus what happened to Young Comrade and how. To do this, they divide themselves into two groups - three of them play the original Four Agitator and the fourth plays, the now dead, Yong Comrade. When the young meets the Four Agitators at the Chinese border, he asks them whether they have brought with them locomotives, tractors, seeds and machine guns. But they explained to him the great importance of their propagational mission, which is to bring to the Chinese workers 'the teaching of the classics: the ABC of Communism,' 'class-consciousness,' and 'and practical knowledge of revolution.' He agrees with them that these are more important than providing the workers with their urgently needed materials i.e. locomotives, tractors, etc... from the very beginning the Young Comrade seems to be morally and politically class conscious; he is quite aware that his mission is to fight 'against exploitation and ignorance for a classless society.' (Note ${ }^{6}$ ) He joins the other agitators on the ground that he will take part in spreading political knowledge of revolution. To facilitate their 'illegal' work, the educators put on masks and by doing this, they: 
Do not give up their individuality by effacing themselves and adopting the personae of workers.

They only give up their individualist identity, their reified 'is-ness,' the false consciousness with which grandiose notions of their historic significance has taught them. What they put on is their social individuality, their 'badge' of both eternity and society. ( Note $^{7}$ )

The effectiveness of masks as a device to efface the private individualities of the Agitators is undermined by the apparently romantic or passionate nature of the Young Comrade. The Young Comrade seems to be not so rigidly disciplined and died to the Party Line as the Four Agitators, for his passionate human nature brings him to speak openly and sympathetically to the oppressed and exploited Coolies. This means that his human passion and sympathetic understanding, though at certain times uncalled for, overshadows his dispassionate thinking. His humanism, in short, takes the best in him as far as the party line is concerned simply because when and where it matters his feelings supersede his dialectical thinking. This 'naivety' of the Young Comrade undermines their mission as far as the Four Agitators can see it, simply because he has already proven to have 'separated feeling from reason' $\left(\right.$ Note ${ }^{8}$ ). However, this does not cast a shadow of doubt about the genuineness of his Marxist thinking particularly when he addresses the workers, saying 'Give up whatever you own Comrades! You have nothing!'(Note ${ }^{9}$ ) The young Comrades words echo the words of Marx and Engels who chose to end their Communist Manifesto with when urging the worker to be active and ready to give up everything which will mean winning everything should the workers triumph in their revolution, that was their final advice before they raised their historic motto "Working Men of All Countries, Unite!"(Note $\left.{ }^{10}\right)$ But this excessive revolutionary zeal makes him act according to his on individual understanding of Marxism, and most of the time he 'acts according to a political instinct, and out of pity rather than calculation.' (Note ${ }^{11}$ )

The mode of behaviour mediated by the Young Comrade in his response to their given reality is an objective expression of his understanding of Marxism proper. But this does not mean that he is a homogenous type of character. He experiences the inner dialectics of power politics in the sense that Brecht uses him as a medium through whom he can demonstrate the contradiction in the reifying ideologies adopted by a given Party as an ideological state apparatus.(Note ${ }^{12}$ ) Through him, Brecht demonstrates the dialectics between feelings and reason, body and mind, theory and practice. When, for example, he talks to the workers urging them not to go to the factory, some of them refuse to strike showing money offered to them for not participating in an earlier strike. He slaps the money from a worker's hand, and does not sympathise with him though he has 'got a wife and three children,' while, as we have seen, he behaves differently with their coolies.

In Britannia, Howard would abstract scenes from history presenting them in the form of a dream to aplot the spiritual progress of Christian Wager through English history." This history is seen through the characters that are depicted as "motionless figures," and they "will stay like that if nothing stirs them. They are the nation. United in its living citizens. In all the dead who've gone before. In the people not yet born."(Note ${ }^{13}$ ) This is known spontaneously to Wager 2 who uses the same language of the people, who are drawn away from giving a positive participation in making history, to the extent that their role in society moves under pre-arranged steps by the dominant ideology. In The Measures Taken, the coolies express a similar feeling of oppression unless a revolutionary power arises.

The agitators in The Measures Taken come from another country, whereas in Britannia, the agitator "rises from among the figures, moves among them, waking them." $\left(\right.$ Note $^{14}$ ) That Agitator, unlike those in The Measures Taken who move on a Marxist basis, moves on a religious basis. He demands that the English society lives its oppression deeply by two harmonious forces: "outward oppression relies on inward cancer to turn a man bad. Under licence, torturers gather into a pact they call power." (Note ${ }^{15}$ ) The Agitator's speech could be understood according to what Howard describes as the 'collapse' of the English society by both the American imperialism and the English Capitalism. This collapse is the outcome of the outward and inward forces united together in the so-called 'power.' But 'power,' as Regicide (The Agitator) sees it, is "something from the people." For him, the "king" is a symbol of rule, and he wants to get rid of that type of rule. His weakness, however, is that he is a "political pacifist," and his thought is a Utopian visionary of the religious mystique: "I would have found Christ where I left Him, but He is risen."(Note ${ }^{16}$ ) Regicide believes that human beings should be side to side level. Not very similar to Regicide, Wager 1's personality is of a contradictory nature, he is a powerless individual who wishes to be effective, but when he gains "power," he has not got the ability to express himself because he has 'lost his voice.' (Note ${ }^{17}$ ) He is a man of decisions but he has no power to decide, a man of no intellect but he has no power to act.

Some of the Characters in Britannia are hopeless and helpless figures; they see things only through their own social and historical experience in their society. Throughout history, the rulers knew how to keep governing the people properly: "they served out shit in a large tin can, /a teaspoon to everyone;/I got so fat I couldn't stand,/to fight in the hungry army." (Note ${ }^{18}$ ) Similarly, in The Measures Taken, the Chinese merchant is quite aware that he should give the Coolie "Just enough rice to stay alive that he can work" (Note ${ }^{19}$ ) for him. In both plays, we find that power-holders, rulers, merchants, etc... have enough experience, to manipulate the people, to persist in their position. According to Howard, Thatcher in Britannia, for instance, is a "traitor! She makes even her enemies her slaves" (Note ${ }^{20}$ ) and the Chinese merchant knows well how to "handle a coolie" to make him work for "almost nothing."

In The Measures Taken, the Young Comrade is sent once to the Chinese merchant to encourage him to arm the Coolies against the English merchants. Of course, the merchant is not a mere individual, he is there to serve a purpose i.e. a social, and political, one. He is a type, an idea brought to life by Brecht's dramatisation. In other words, he is a representative of the dominant ideology of Capitalism in the play. Brecht presents him as the concretion of exploitation and self-interest. If we want to evaluate him in the light of these qualities, he is behaving in accordance with his own 
trade (everything is money). He is dealing with his own exchangeability of commodities, be they objects or human. The idea into exchangeability or the transformation of use-value commodities into exchange-value commodities i.e. the transformation of Quality into Quantity, is well-illustrated in the song of Commodities which the merchant sings "I don't know what rice is/ All I know is its price/... I don't know what cotton is/All I know is its price/....I don't know what man is/All I know is his price." (Note ${ }^{21}$ ) Realizing that the English merchants and the Chinese merchant are two sides of the same coin, the Young Comrade places honour above all else, "neither smiles nor threats could compel him to eat" with that merchant" and he rises, breaking off the discussions. Consequently the workers get no arms.

As far as the merchant is concerned, and as far as Brecht sees him as a representative of Capitalism, potential classconsciousness is reified into self-consciousness, i.e. he sees everything in terms of money. In the light of what it has been just said about the Chinese merchant's mode of behaviour, and if we try to juxtapose this mode of behaviour against that of the Young Comrade, who is in this particular moment sharing the merchant the social and political situation i.e. business transaction, he is there to conduct with the merchant, but we find the Young Comrade's behaviour to be partially faulty when we, as spectators or readers, do not expect to find that in him. In other words, what Brecht is doing here is moving from the inner world of the individual, the inner dialectical relationship between the Young Comrade to the Four Agitators, into the wider spectrum of society and history at large, he is historicising this relationship rather than keeping it as internal issue. Nor would it, simultaneously, mean that the dramatic action would remain confined to taking place between 'comrades' and the oppressed on the one hand, and exploiters, on the other hand.

In Britannia, Howard presents certain characters that are the representatives of Feudalism and others as representative of Capitalism in their ideologies which are based on oppression and exploitation of people, no matter how their policy affects negatively, and damages society both economically and politically. These representatives unify in all ways to form power, in different types, in order to persist in their exploitation and oppression, changing their old forms into more clever new ones. The dialogue between the Soviet Ambassador, Plodkin, and Thatcher indicates how the latter is a well-experienced woman. She knows how to "approach governing Britain" (Note ${ }^{22}$ ) by what she expresses "to be born again. It may not seem orthodox to you [Poldkin] but it's the old way and it's English.”(Note ${ }^{23}$ ) But Poldkin's problem is that he is involved in usury which is the essence of the 'free market' about which he says Thatcher "you play the market and elevate usury into the soul of the nation, but my wheeling and dealing condemns my soul and my nation to subjection."(Note ${ }^{24}$ ) To which Thatcher says "but it is not my fault you state's founded on such a purist principle that signing a cheque disgusts you. Discard principle, I say. You'll feel better."(Note ${ }^{25}$ ) Being involved, Plodkin knows the danger of his role in corrupting the economy of his society, and being 'bought' he cannot withdraw.

In his comments on the way the individual is not only influenced by, but also as being the product of, the environment with which $\mathrm{S} /$ he is enculturated and brought up, Howard writes "it is natural if you grow up in a society, your way of seeing reality will be marked by your experience of that society."(Note ${ }^{26}$ ) The characters in Britannia are restricted and limited in their thought to the ubiquitous discourses of the society they were brought up in; they are consumers and distributers of the dominant ideology of their society. It is clear in what Hooker says as he tries to separate between his love for his country and his prejudiced feelings towards 'other' nations: "love of country has nothing to do with hatred of other nations." (Note ${ }^{27}$ ) In supporting the same idea, Wager is supposed to be disrupting the mechanistic or the linear process of the English history which is based mostly on 'Hard Facts;' for the English history dealt with situations irrespective of the people or peoples involved in those situations: "king: What country are you going to? Wager: Wherever this country comes to./King: And there is it going? Wager: It will go where its love leads." (Note ${ }^{28}$ ) The English cared only for their individual interests; they cared only for the individual 'I'. Wager, also, is an example of that, he does not care about what happens to Wager 2 who appears "in between other people's words." (Note ${ }^{29}$ ) Wager 2 considers that "humanity is a cult which has a certain vogue in taking shops where words are referred to reality." $\left(\right.$ Note $^{30}$ ) Wager 2, like other people, sees things in their physical immediacy i.e. as appearances: "when I am in church, when I look at the bread, it is bread, when I look at wine, it is wine... I hear the words and feed on God's spirit, that is all. He gave his body for me, for my body, once and once is enough for me...Christ is in me and me in Him, so we are one. He feeds me, I grow his grain. That's the deed. His deed at the Cross, mine in the field." (Note ${ }^{31}$ ) Wager 2 is more radical in her thinking than Wager 1 , to whom she states that "power has to be gained." (Note ${ }^{32}$ ) But her contribution to the process of history is negative, for she is always at the side of the strongest, or at least she does not show any sort of real objection to what is going around. She says to Inguar "if you kill him [Wager], I'll go with you willingly." (Note ${ }^{33}$ ) Again, she points out to Christ that she was "Wager's slave. Then Inguar came. I was his slave. He killed Wager...came here. Inguar also turned...to you. So I'm Wager's slave." (Note ${ }^{34}$ ) She is quite aware of what is going around, but that awareness is not transformed into positive action except, as an example, when she reserves the counter-reformation to the point of scarifying her life in scene 8 , she has some-class-consciousness as when she is a field worker in scene 8 there is some materialism in her thinking.

In Britannia, Wager 1 tells Wager 2 his dreams, in which a man steals the Book from him. Then a "man in justice's" robe sees him. The reaction of the man in justice's robe is pushing bread into the throat of the man who has stolen the Book till he becomes sick. This dream, on which Wager 2 comments that "books are dangerous," shows that rulers, represented in the dream by the man in "justice's robe," are quite aware of their interests; they know where the danger that threatens them lies. In other words, they do not want the people to be class conscious. And, pushing bread into the throat of the man who has the Book might come to mean keeping him unable to speak. In The Measures Taken, the policeman arrests a worker for having a leaflet. The way the man in "justice's robe" follows is much more dangerous than that of the policeman, for this action makes an essential conception, which is class struggle, not so much clear. 
In the Measures Taken, the leaflets which the Young Comrade distributes, are to the policeman "more dangerous than ten canons," simply because, he, i.e. the policeman, sees them as "subversive" material. The idea that these leaflets are illegal to distribute among the workers is predefined by the fact that the policeman is the representative of "The Establishment" and the Status Quo or the reigning government, with its ideological state apparatus which authoritarianly controls the propagation and dissemination of ideas. As a corollary to this, the policeman is in no position but to serve the 'law -and -order' at the expense of 'justice;' a 'justice,' which we come to believe that the Four Agitators and the Young Comrade are there to ideologically teach Chinese workers to embrace. But what the Four Agitators suggest is that the Young Comrade "could have told the workers... Because the policeman had committed an injustice" (Note ${ }^{35}$ ) seems to be a shy expression, for Marxism does not teach or imply that the workers should think that their exploiters or the police "had committed an injustice," but rather it teaches that even the existence of the police, so to speak, is an injustice in itself. They are, i.e. the policemen, more or less "the chief instruments of force of the state power" (Note ${ }^{36}$ ) which is, i.e. the state in Lenin's words "a product of the irreconcilability of class antagonisms." (Note ${ }^{37}$ )

There is a sort of chaos in Britannia. Everything is muddled up, and the oppressed appear in the form of 'Gangmen Chorus' who express their state of unbearable oppression: "the priest must be hanged, and the Bibles all burnt,/for fear rulers' justice from them should be learnt." (Note ${ }^{38}$ ) The rulers want to defend the old notion that they are placed in their positions by God and whatever they do, is, therefore, a fulfilment of a divine will, an idea that is echoed in Howard's note elsewhere "they have always liked us to imagine we are praising God when we obey them." (Note ${ }^{39}$ ) In other words, what the Gangmen want to say is that everything the rulers use to give justifications for their actions must be destroyed completely.

In The Measures Taken, the deterioration of the social, political and economic situation persuades the Young Comrade that it is the time they start revolution; while the other Four Agitators do not approve of his optimistic evaluation of the given situation. They claim that the proletarian movement still lacks fighters and weapons, and that their "own responsibility" is much greater. But the Young Comrade can see nothing except the 'oppression' and 'misery' which 'can't wait.' His wondering "Who is the party?" and "Does it sit in the house with a telephone?" with "secret thoughts" and "unknown decisions" become justified, and above all what sort of "party' is that which cannot adopt the uprising of the masses? His wrongdoing is justified and that reflects a political-consciousness in accordance with his human sympathy. This brings to mind the struggle between Rosa Luxemburg and Lenin about a better type of Party. (Note ${ }^{40}$ ) About the spontaneity theory Brecht writes "in a sort of way I would have to have argued against the party. But I have no intention of chopping off my foot just to prove that I am handy with an axe." (Note ${ }^{41}$ )

The inability of the instructions to give a proper solution in such a decisive historical moment makes the Young Comrade tear up writings which are "worth nothing", to him, unless they are capable of giving the proper revolutionary solutions in such situations. In a moment of emotional impact he takes off his mask and says: "We have come to help you. We have come from Moscow." (Note ${ }^{42}$ ) Again he endangers the whole group and makes them be looked upon as foreigners and troublemakers. Consequently the Agitators try to flee but they cannot smuggle him out for fear he might be later discovered. So in five minutes pause to consider the question, they decide that he must be killed, and his body must disappear. The Control Chorus agrees with "the measures taken."

The feeling that the Agitators are strangers and potentially troublemakers arises in the minds of the Chinese workers from the political spontaneism, in other words from their political immaturity since they approach their situation of being on strike in terms of "tactics - as - policy." Thus, one might argue from the Marxist-Leninist point of view, as Brecht demonstrates it in the dialectics of his play that, class-consciousness and political knowledge should come, at best, from within a given society, which would prove the political, social and economic i.e. the ideological and historical, readiness and ripeness to undergo a revolutionary change; a readiness which Marx emphasised as the prerequisite for any such a change. In this sense the help which the Agitators are there to offer to the Chinese workers is seen by these latter as an outside interference in, what they see as, their own private affairs. This brings to mind the contentious question of "Who triggers the revolution?"

In Britannia, there is a sort of recreation of a new form of rule. It is the old one but in a new shape. The King and his advisers define, in accordance with what their own individual interest, what "state," "soul," "liberty," "love," "force," "loyalty" are... By adding up all these "little local patriotisms," says Lord 2 "your Majesty, the soul can rise to a worldwide empire" (Note ${ }^{43}$ ) which is, as the King illustrates it, "consent and creative direction," or more than that, as he says "we change our forms but we are true to the past, we resurrect its spirit." (Note ${ }^{44}$ ) A sense of Englishness is to be defined after that. It is demonstrated by the King "this most good government will provide for the good of the people. A people pleased with their position, filled with love and boldly ready to fight for the public cause which is their own." $\left(\right.$ Note $^{45}$ ) In the midst of long applause to the policy, the Regicide recognizes the truth that "Error is eternal."

The contradiction, the frustration, the hypocritical policy etc. make the characters of Britannia unable to be in a proper position to realise where they are. There is a kind of monologue going inside Wager, and one part of that monologue takes the form of Wager 2 to whom Wager says "you are my other side." Wager1 expresses his mind at the very beginning of the play in what sounds fine words standing for what Wager 2 describes as "fine feelings" and Divine describes as "patriotic words, no doubt." (Note ${ }^{46}$ ) He seeks power to "stop torture going on around me." But the frustration he experiences weakens him to the extent that he says: "I go where I cannot come," $\left(\right.$ Note $\left.^{47}\right)$ and therefore he is later led to the conclusion that "I'm young and must pursue my course. That is my hope. I will go where its love leads." (Note ${ }^{48}$ ) And at the end of the play, he makes what seems to be a final and eternal confession: "I am Christian 
Wager, do truly and sincerely acknowledge, profess, testify and declare, in my conscience, before God and the world, that sovereign Queen Britannia is lawful and rightful queen of this realm..."(Note ${ }^{49}$ )

Regicide is a dramatic representation of the desired marriage between Wager 1 and Wager 2, because he represents an ideal human being, in comparison with the others available. Britannia is presented as a dream in which characters undergo mutational, progressional process. In it Wager, as an instance, metamorphically becomes at one stage a farmer when he talks to Inguar, then a king, then a Baker, a priest and then a soldier. But his psychic metamorphosis remains only skin-deep. In this sense, he is like the Young Comrade in using the mask. He tries to change the outside of himself to give the impression that he is different inside, but he, nonetheless, remains the same inwardly. The essential human nature of the Young Comrade is the right one.

Still, the discussion of who was "right" and who was "wrong" in The Measures Taken, or whether the Young Comrade deserved that extremely ruthless, or even brutal, verdict by the Four Agitators on revolutionary grounds or they could have dealt with the issue differently cannot escape the historically momentous event whereby an individual was killed by his comrades when he was working to achieve the same target they were after. The Four Agitators act according to certain steps drawn by the dictatorship of the party not only over its individual members, but also over the proletariat. According to this, the Four "masked Agitators" could commit their cruel act, because as "faceless men they become effective, reliable, will-less, tools in the hands of the party." (Note ${ }^{50}$ ) Thus the Control Chorus's song in praise of the Party in merely a weak pretext, it reflects nothing but a justification for the Party: "The individual has two eyes/ The party has a thousand eyes." (Note ${ }^{51}$ ) This song is here only to depict the role of the individual as less important. And, by singing it, they neglect that "the individual exists only in the connection that leads to the universal. The universal exists only in the individual and through the individual." (Note ${ }^{52}$ ) The Four Agitators keep the Young Comrade because they are "still in need of his help" (Note ${ }^{53}$ ) and when they decide to get rid of him they are capable of giving justifications. Howard explains:

The crux of the matter is that the Agitators have the sanction of the authority of 'Scripture' behind them. They own the idea. Consequently they claim property rights over the understanding of it. It is a sanction they hold over the Young Comrade and finally they use, whereas the young Comrade has no authority at all apart from his individual understanding. (Note ${ }^{54}$ )

To make the verdict less brutal, Brecht adds a sequence in which the Young Comrade consents to be killed, "But even if he does not agree with us," says the second Agitator "he must disappear completely." (Note ${ }^{55}$ ) This is the Stalinist interventionist, centralist leadership in the mask of the Democratic centralism. Christine Kiebuzinska reads the way the verdict of the Four Agitators, as representatives of the Party, against the Young Comrade in the light of the Stalinist way in executing their comrades, it is the "Stalinist" method "and the disappearance of comrades who did not submit to the party discipline was coming up into style." (Note ${ }^{56}$ ) But the "crucial event" in The Measures Taken, says Roger Howard: "is not the execution ... Rather it is the pause... The failure of the play is that the pause remains silent." (Note ${ }^{57}$ ) Indeed, it is the point where the play cannot draw a different trajectory instead of showing impotence and passivity by resorting to silence. The five minutes pause in the play, is to serve a dramatic purpose which is to demonstrate that this is what is, and what could be, happening under a dictatorial leadership i.e. executions and "show" trials in the Stalinist manner. The fact that the Four Agitators pose to the audience the question of what is to be done, in a way undermines the absolutism with which they carried their murder of the Young Comrade, because if the pause proves anything, it proves their own uncertainty of what should be really done. In other words, they are evoking the sense that there is another alternative to killing the Young Comrade. This is implied in the nature of the ideological grounds from which the question "What is to be done?" arises. And this contradicts the action of the Four Agitators and proves it to be undialectical. In the light of the decision to kill the Young Comrade, we may hazard the idea that their mode of behaviour is not different from that of the Young Comrade in his dealing with the Chinese merchant. In this sense, the Four Agitators are like the Young Comrade, for they all work upon the immediacy of the feelings. And this may concur with Brecht's "understanding and use of Lenin" to become "more dialectical and more in line with the principle of democratic centralism." (Note ${ }^{58}$ ) In "He Who Says No," the Boy does not consent to be left alone to die and breaks the custom expressing the need for "a new Great Custom to be introduced at once, to wit, the Custom of rethinking every new situation." (Note ${ }^{59}$ )

\section{Conclusion}

In The Measures Taken, the Four Agitators spread "the ABC of communism," but they lose their dialectical thinking. And, in Britannia the power sought by Wager is transformed to suit his own interests. He, nevertheless, achieves power but becomes will-less. He is absorbed by the powerholders, and his final submission is, more or less, the submission of the English.

In the final review of The Measures Taken, the audiences or readers are likely to have a kind of mixed feelings regarding its overall treatment of the Young Comrade, his mission and the Four Agitators verdict on him, while the play "confronts the audience with basic questions of revolution: violence, discipline, the structure of the Party, the relationship to the masses, ...,"(Note ${ }^{60}$ ) it, simultaneously, teaches them a significant lesson that the details of the revolutions cannot be speculated or foreseen, nor could the task of revolutionaries be easy and without losses and, possibly, inescapable sacrifice. In a word, the importance of the play lies in its subject matter which provides material from which we may learn. It is true that in Britannia, the "organised revolutionary power," is completely absent, and the play remains a "record," but this record raises the question in the mind of an honest man: What shall, or could, be done in such circumstances? 


\section{References}

Althusser, Louis . "Ideology and Ideological State Apparatuses" in Lenin and Philosophy and Other Essays, trans. Ben Brewster (Bristol: Western Printing Services, 1971), 23-73

Engels, Frederick. The Origin of the Family, Private Property and the State in Karl Marx and Frederick Engels, Selected Works, Vol. 3, Moscow, 1973.

Brecht, Bertolt. The Measures Taken. Trans. Carl R. Mueller, in The Measures Taken and Other Lehrstüke. London, 1989.

Brecht, Bertolt. He Who Says No. Trans. Wolfgang Sauerlander, in The Measures Taken and Other Lehrstüke. London, 1989.

Brooker, Peter. Bertolt Brecht: Dialectics, Poetry, Politics. London, 1989.

Howard, Roger. Britannia, in Britannia and Other Plays. UK, 1990.

Howard, Roger. 'Comments on Underground Theatre, Volker Braun and the Historical Moment,' in Contradictory Theatres, ed. Leslie Bell.pp.222-27,

Howard, Roger. “"The Dramatic Sense of Life:” Theatre and Historical Simulation,' in New Theatre Quarterly, Vol. 1 No 3, pp.164-72.

Howard, Roger. 'A Measure of The Measures Taken: Zenchiku, Brecht and the Idealist Dialectics,' in Praxis 3, pp. 164 -9 .

Kellner, Douglas. 'Brecht's Marxist Aesthetic: The Korsch Connection,' in Bertolt Brecht: political Theory and Literary Practice, ed. Betty Nance Weber and Heinen. Pp.29-42.

Kiebuzinska, Christine. Revolutionaries in Theatre-Meyerhold, Brecht, and Witkiewicz. London, 1988.

Lenin, V.I., The State and Revolution. Peking, 1976.

Lenin, V.I., 'On the Question of Dialectics,' in Collected Works, Vol. 38.pp 359 - 63.

Marx, Karl. Friedrich Engels, Chapter IV. Sec. II in The Communist Manifesto, London. 1848.

Spiedel, Erich. 'The Individual and Society,' in Brecht in Perspective, ed. Graham Bartram and Anthony Waine. London, 1987. pp. $45-62$.

Willet, John, Brecht on Theatre. London, 1973.

Thalheimer, August. “Rosa Luxemburg or Lenin” 1930, Marxist Internet

Archive,http://www.marxists.org/archive/thalheimer/works/rosa.htm. Also see Helen C. Scott and Paul Le Blanc, "Introduction to Rosa Luxemburg", in Socialism or Barbarism: The Selected Writings of Rosa Luxemburg, ed. by Paul Le Blanc and Helen C. Scott. London: Pluto Press, 2010, 3-35.

Williams, Raymond . Writing in Society, UK: 1983/91.

\section{Notes}

Note ${ }^{1 .}$ See, for example, Raymond Williams, Writing in Society (UK: 1983/91).

Note ${ }^{2 .}$ John Willett, Brecht on Theatre (London: 1973), p.79.

Note $^{3 .}$. Roger Howard, 'Comments on Underground Theatre, Volker Braun and the Historical Moment,' in Contradictory Theatres, ed. Leslie Bell (England: 1984), p.224.

p.224.

Note ${ }^{4}$. Ibid., p.227.

Note ${ }^{5 .}$ Hohn Willerm, Brecht on Theatre, pp. 121-129.

Note ${ }^{6 .}$ Bertolt Brecht, The Meaures Taken, Trans. Carl R. Mueller, in The Measures Taken and Other Lehrstüke (London: 1989), p.10.

Note $^{7}$ Roger Howard,“ 'The Dramatic Sense of Life: Theatre and Historical Simulation,' in New Theatre Quarterly.

(Vol. 1 No 3, 1985), p.268.

Note ${ }^{8}$ Brecht, The Measures Taken, p.18.

Note ${ }^{9 .}$ Ibid., p.15.

Note ${ }^{10 .}$ Marx and Engels write 'The proletarians have nothing to lose but their chains. They have a world to win.' see Karl Marx , Friedrich Engels, Chapter IV. Sec. II in The Communist Manifesto (London: 1848).

Note ${ }^{11}$. Peter Brooker, Bertolt Brecht: Dialectics, Poetry, Politics (London: 1988).p.192.

Note $^{12}$. For examination of the issue, see Louis Althusser, "Ideology and Ideological State Apparatuses" in Lenin and Philosophy and Other Essays, trans. Ben Brewster (Bristol: Western Printing Services, 1971), 23-73.

Note ${ }^{13 .}$ Roger Howard, Britannia, in Britannia and other Plays ( UK: 1990), p.109.

Note $^{14}$. Roger Howard, Britannia., p.109.

Note $^{15}$. Ibid., p. 125.

Note ${ }^{16 .}$ Howard, Britannia, p.137.

Note ${ }^{17 .}$ Howard, Britannia, p.138.

Note $^{18 .}$ Howard, Britannia, p.135. 
Note $^{19}$. Brecht, The Measures Taken, p.23.

Note $^{20 .}$ Howard, Britannia, p.131.

Note $^{21 .}$ Brecht, The Measures Taken, pp. 23-4.

Note $^{22 .}$ Howard, Britannia, p.130.

Note $^{23 .}$ Howard, Britannia, p. 130.

Note $^{24 .}$ Howard, Britannia, p.131.

Note $^{25 .}$ Howard, Britannia, p.131.

Note $^{26 .}$ Howard, 'Comment on the Underground Theatre,' ....in Contradictory Theatres,p.223.

Note $^{27 .}$ Howard, Britannia, p.127.

Note $^{28 .}$ Howard, Britannia, p.128.

Note $^{29 .}$ Howard, Britannia, p.131.

Note $^{30 .}$ Howard, Britannia, p.110.

Note $^{31 .}$ Howard, Britannia, p.124.

Note $^{32 .}$ Howard, Britannia, p. 110.

Note $^{33 .}$ Howard, Britannia, p.113.

Note $^{34 .}$ Howard, Britannia, p.116.

Note $^{35 .}$ Brecht, The Measures Taken, pp. 21-2.

Note $^{36 .}$ V.I. Lenin, The State and Revolution (Peking: 1976),p.12.

Note $^{37 .}$ Lenin, The State and Revolution. pp.10 ff. See also, Frederick Engels, The Origin of the Family, Private

Property and the State in Karl Marx and Frederick Engels, Selected Works, Vol. 3, Moscow, 1973, pp. 326-27.

Note ${ }^{38 .}$ Howard, Britannia, p. 133.

Note $^{39 .}$ Howard, 'Comments on Underground Theatre..' in Contradictory Theatres. p.226. s

Note $^{40 .}$ August Thalheimer, "Rosa Luxemburg or Lenin” (1930), Marxist Internet

Archive,http://www.marxists.org/archive/thalheimer/works/rosa.htm. Also see Helen C. Scott and Paul Le Blanc,

"Introduction to Rosa Luxemburg", in Socialism or Barbarism: The Selected Writings of Rosa Luxemburg, ed. by Paul Le Blanc and Helen C. Scott (London: Pluto Press, 2010), 3-35.

Note $^{41 .}$ Brooker, Bertolt Brecht: Dialectics, Poetry, Politics, p.193.

Note $^{42 .}$ Brecht, The Measures Taken, pp.29-30.

Note $^{43 .}$ Howard, Britannia, p.128.

Note $^{44 .}$ Howard, Britannia, p.128.

Note $^{45 .}$ Howard, Britannia, p. 129.

Note $^{46 .}$ Howard, Britannia, p. 125.

Note $^{47}$ Howard, Britannia, p.128.

Note $^{48 .}$ Howard, Britannia, p.138.

Note $^{49}$. Howard, Britannia, p.138.

Note ${ }^{50 .}$ Erich Speidel, 'the Individual and Society,' in Brecht in Perspective, ed. Graham Bartram and Anthony Waine (London: 1988),p.96.

Note ${ }^{51 .}$ Brecht, The Measures Taken, p.29.

Note $^{52 .}$ V.I. Lenin, 'on the Question of Dialectics, 'in Collected Works (Vol. 38),p.361.

Note $^{53 .}$ Brecht, The Measures Taken, p.25.

Note $^{54 .}$ Roger Howard, 'A Measure of “The Measures Taken:” Zenchiku, Brecht and Idealist Dialectics,' in Praxis, No. 3, (1976),p.170.

Note ${ }^{55 .}$ Brecht, The Measures Taken, p.33.

Note ${ }^{56}$. Christine Kiebuzinska, Revolutionaries in the Theatre-Meyerhold, Brecht, and Witkiewicz (London: 1988),

p.96.

Note ${ }^{57 .}$ Howard, 'A Measure of "The Measures Taken...,p.171.

Note $^{58 .}$ Brooker, p.196.

Note $^{59}$ See Bertolt Brecht, He Who Says No, trans. Wolfgang Sauerlander, in The Measures Taken and Other

Lehrstüke (London: 1989), p.79.

Note ${ }^{60 .}$ Douglas Kellner, 'Brecht's Marxist Aesthetic: The Korsch Connection,' in Bertolt Brecht: Political Theory and Literary Practice, ed. Betty Nance Weber and Heinen (UK: 1976),p.35. 